\title{
Sisters Network, Inc.: the Importance of African American Survivor Advocates in Addressing Breast Cancer Disparities
}

\author{
Karen Jackson ${ }^{1} \cdot$ Mary Waters $^{2} \cdot$ Lisa A. Newman ${ }^{3}$ \\ Accepted: 29 January 2021 / Published online: 9 March 2021 \\ (C) The Author(s), under exclusive licence to Springer Science+Business Media, LLC part of Springer Nature 2021
}

\begin{abstract}
Purpose of Review To explain the role of African American survivor advocates in addressing breast cancer disparities. Recent Findings The Sisters Network, Inc. is a national African American survivor advocates organization, founded in Houston Texas in 1994 and active today via affiliate chapters throughout the United States as well as its national headquarters. The Sisters Network provides essential outreach, educational, and research support to the breast oncology community.

Summary The breast oncology community should partner with the Sisters Network and support their activities in efforts to achieve breast health equity.
\end{abstract}

Keywords Breast cancer $\cdot$ Disparities $\cdot$ African Americans $\cdot$ Advocacy $\cdot$ Survivors

Steady gains in breast cancer survival rates that have occurred over the past several decades can be attributed to screening programs for early detection as well as clinical trials resulting in improved treatments. Large-scale, effective screening programs and robust clinical trials accrual is heavily dependent upon partnerships with survivor advocacy organizations. Survivor advocates are powerful and trusted members of the oncology patient population, and this is particularly true in the field of breast cancer where advocates have spearheaded the implementation of various breast cancer diagnostic and therapeutic advances. Breast cancer survivor advocates have served as ambassadors to promote mammographic surveillance in the workplace, in churches, and through print, broadcast, and social media. They have been foundational partners in philanthropic research fundraising efforts. Advocates serve as indispensable reviewers of grants and protocols as well as study co-investigators, ensuring that issues of survivorship and quality of life are appropriately prioritized. They have also

This article is part of the Topical Collection on Breast Cancer Disparities

Lisa A. Newman

lan4002@med.cornell.edu

1 Sisters Network, Inc., Houston, TX, USA

2 Sisters Network, Inc., Detroit, MI, USA

3 Department of Surgery, Weill Cornell Medicine, 420 East 70th Street, New York, NY 10021, USA been fundamental partners in legislative advocacy, calling for the protection of government funding for research. Survivor advocacy in the twenty-first century also features widespread breast health messaging through the full spectrum of social media outlets.

African American women have a more advanced stage distribution compared to White American women [1]; they experience higher death rates from breast cancer [1] and are more likely to be diagnosed with biologically aggressive phenotypes such as triple negative breast cancer (TNBC) [1]; and worse outcomes have also been reported among African American compared to White American patients with hormone receptor-positive disease stratified by gene expression profiling [2]. Mammography screening for early detection and improved outcomes from TNBC is therefore especially relevant for African American women [3]. Furthermore, research to evaluate the genetic and biologic determinants of breast cancer disparities should be an imperative in efforts to achieve cancer health equity, yet African Americans are disproportionately under-represented in oncology clinical trials [4].

Clearly, African American survivor advocates can play a unique and vital role in addressing breast cancer disparities [5]. The oncology community is therefore extremely fortunate to partner with the power and strength of the Sisters Network, Inc., a national African American breast cancer survivor advocacy organization [6]. The mission of the Sisters Network is based on a commitment "to increasing local and national attention to the devastating impact that breast cancer has in the 
African American community" and their goal is to "reduce the mortality rate of breast cancer among African American women by generating awareness, garnering attention, providing access to information and resources, and supporting research efforts in the ecosystem". 7

The Sisters Network was founded in October 1994 by Karen Eubanks Jackson, CEO, an African American woman who was diagnosed with breast cancer earlier in 1993 and has survived being diagnosed four additional times with breast cancer. Her experiences and observations while undergoing breast cancer treatment motivated Jackson to create an advocacy organization dedicated to addressing the unique needs of African American women. The scope of these needs is broad and ranges from the availability of more diverse hairpieces/ wigs and mastectomy prostheses compatible with African American skin tones to increasing breast health awareness and treatment opportunities among the general African American community. Jackson's efforts began with a meeting of 15 women in 1994. Today, the Sisters Network has evolved into a national organization of more than three dozen affiliate chapters spanning from the east to west coasts of the United States $[6,7]$.

"Stop the Silence" is the national slogan for the Sisters Network Inc., chosen in the organization's effort to acknowledge the predisposition of many African Americans to mistrust and fear the medical establishment. These inclinations, coupled with health care access barriers created by socioeconomic disadvantages, systemic racism contribute to the inferior outcomes that are reported for African Americans compared to White Americans related to a spectrum of both benign and malignant diseases. Sisters Network members invest their time, dedication, and energies into their commitment to improving early breast cancer detection among African American women through standardized regional, community-based as well as national outreach and education programs. Under the leadership of the national headquarters, Sisters Network membership also vigorously support research by encouraging breast cancer clinical trial participation and by encouraging investigators and funding agencies to address questions related to the breast cancer burden of African American women.

The Sisters Network membership empowers new members, newly diagnosed patients and the African American community in general, with the most updated information possible regarding the prevention, early-detection, and multidisciplinary treatment options for breast cancer, including participation in clinical trials. The organization itself has actively participated in a variety of multicenter research programs related to breast cancer pathogenesis and survivorship. Members of the Sisters Network have served on advisory boards for Susan G. Komen for the Cure, the National Cancer Institute, and the American Cancer Society [6]. Founder and current CEO Karen Jackson has been the recipient of numerous awards and accolades, including BET Her Fights Breast Cancer TV Award, Ebony Magazine Power 100 List, JC Penney "Champion of Change," TNT Dramatic Difference award, Breast Cancer Hero by Lifetime TV, The Jefferson Award-NBC, Top Ladies of Distinction Inc. "Status of Women award," National Council of Negro Women Inc. Impact Service Award, Vanderbilt-Ingram Cancer Center award, ICC- Hope Award, Founders Award for Leadership, BET award, "History Maker in the Making" the Lance Armstrong, "Voice of Survivorship." [7]

As described in greater detail on their website [7], a few of the many highlights of the Sisters Network activities include the following:

- The annual Gift of Life Block Walk, in which members walk door to door in neighborhoods composed predominantly of African American residents and inform women in these communities about breast cancer surveillance

- Sisters Network Inc. National Breast Cancer Assistance Program (BCAP), which provides support for individual patients and addresses the financial toxicity of breast cancer treatment. New to this year, the Sisters Network BCAP is provided enhanced support to African American breast cancer survivors afflicted with COVID-19

- Breast cancer patient navigation services

- National African American Breast Cancer Conferences, launched in 1999

- Breast Cancer 10-city Conference Tour

- Stop the Silence National African American Breast Cancer $5 \mathrm{k}$ Walk/Run attracting nearly 7000 participants each year

- Teens4Pink, an innovative award winning teen breast health awareness program

- Sisters Network has provided over \$1 million in conference scholarships to help train African American breast cancer survivors to be advocate leaders in their communities through its national African American Breast Cancer conference.

\section{References}

1. DeSantis CE, Ma J, Gaudet MM, et al. Breast cancer statistics, 2019. CA Cancer J Clin. 2019;69(6):438-51.

2. Albain K, Gray R, Sparano JA, et al. Race, ethnicity, and clinical outcomes in hormone receptor-positive, HER2-negative, nodenegative breast cancer: results from the TAILORx trial Abtsract GS4-07. Paper presented at: San Antonio Breast Cancer Symposium 2018; San Antonio, TX.

3. Chen Y, Susick L, Davis M, et al. Evaluation of triple-negative breast cancer early detection via mammography screening and outcomes in African American and White American patients. JAMA Surg. 2020; (epub ahead of print).

4. Duma N, Vera Aguilera J, Paludo J, Haddox CL, Gonzalez Velez M, Wang Y, et al. Representation of minorities and women in oncology 
clinical trials: review of the past 14 years. J Oncol Pract. 2018;14(1): e1-e10.

5. Lythcott N, Green BL, Kramer BZ. The perspective of AfricanAmerican breast cancer survivor-advocates. Cancer. 2003;97(1 Suppl):324-8.

6. Newman LA, Jackson KE. Advocacy Corner: Sisters Network, Inc. J Oncol Pract. 2009; November 1, 2009:313-314.

7. http://www.sistersnetworkinc.org/mission.html; accessed May 21, 2020.
Publisher's Note Springer Nature remains neutral with regard to jurisdictional claims in published maps and institutional affiliations.

For additional information regarding the Sisters Network, please visit www.sistersnetworkinc.org; contact the organization at 9668 Westheimer Rd., Ste. 200-132, Houston, TX 77063; telephone 713.781. 0255 or 866.781.1808. E-mail infonet@ sistersnetworkinc.org. 